\title{
A Corporate Social Responsibility Framework for Mining Sector Using Analytic Network Process
}

\author{
Tarhan Okan ${ }^{1}$, Iskender Peker ${ }^{1} \&$ Serife Demirelli ${ }^{1}$ \\ ${ }^{1}$ Faculty of Economics and Administrative Sciences, Gumushane University, Gumushane, Turkey \\ Correspondence: Serife Demirelli, Faculty of Economics and Administrative Sciences, Gumushane University, \\ Gumushane, 29000, Turkey. Tel: 0090-456-233-7501 Ext. 2173. E-mail: sdemirelli@ gumushane.edu.tr
}

Received: August 26, 2015

Accepted: November 6, $2015 \quad$ Online Published: November 25, 2015

doi: 10.5539/ibr.v8n12p9

URL: http://dx.doi.org/10.5539/ibr.v8n12p9

\begin{abstract}
The aim of this study is to develop a corporate social responsibility (CSR) framework for mining sector and put forward the differences in the CSR perception and interests of the main stakeholders in mining sector, which are defined as government, mining corporations, and other social stakeholders. Analytic Network Process (ANP), which is a decision making technique with multiple criteria, is used in measuring the criteria to be able to bring out how stakeholders perceive CSR activities of mining corporations and which activities they attach more importance and priority. According to the results, for government institutions the most important main criterion identified is "legal criteria", and for mining companies it is "economic criteria". On the other hand, from the perspective of other social stakeholders, which consists of "academicians, local community, and non-governmental organizations", the results show that the main criterion of "environmental criteria" has the highest importance. Study results clearly put forward the differences among stakeholders' perceptions and interests.
\end{abstract}

Keywords: analytic network process, ANP, corporate social responsibility, CSR, mining, framework

\section{Introduction}

In contrast to the mainstream approach, which argues that the sole responsibility of a corporation is to maximize shareholder wealth, today the question of what responsibilities the corporations have towards society has gained in importance (Carroll, 1991). Corporate scandals, along with environment and climate change issues stemming from corporate activities in the first years of $21^{\text {st }}$ century, have share in this change which have carried the notion of corporate social responsibility (CSR) into a core position (Silberhorn \& Warren, 2007). Moreover, mining industry is one of the industries that the notions of CSR and sustainability, which are used for expressing the corporations' social and environmental impacts, are discussed most (Jenkins \& Yakovleva, 2006).

It is quite hard to say that mining corporations have good reputations in CSR (Kapelus, 2002). The discovery, extraction and processing of mineral resources are claimed to be among the most socially and environmentally destructive activities of humankind (Peck \& Sinding, 2003). It is also asserted that in mining of, particularly gold, the level of those social and environmental negative impacts are substantial (Urkidi, 2010). Similarly, Warhurst (2001) puts forward that most of the environmental disasters and human rights incidents, which set the stage for more concerns in CSR, occur in mining (or oil) sector (see also Jenkins \& Yakovleva, 2006; Hamann, 2003). In Turkey, Soma coal mine disaster which caused 301 miner's death in 2014 is one of the best examples of that situation. In parallel to those claims and sad examples, especially in developing countries, the debates on CSR aspects of mining corporations have become more heated and companies have come up against increased opponent groups' pressure about environment, local community and human rights (Kapelus, 2002; Mutti, Yakovleva, Vazquez-Brust, \& Di Marco, 2012). In the past recent years, those social movements and pressures have become a current issue in Turkey and Eurogold Company's business in Izmir-Bergama gold mine gave reason for a comprehensive "ecological resistance movement" (Coban, 2004 also Ozen, 2009a; Ozen, 2009b).

In order to answer the increasing pressure and criticisms, mining corporations are obligated to give weight particularly to their activities' environmental and social impacts (Jenkins, 2004). Herein, the concept of CSR has an important role for those corporations (Hamann, 2003; Hamann \& Kapelus, 2004). One of the goals of CSR activities of mining companies is considered to ensure their reputation, their access to capital, land, and markets by harmonizing their policy and practices with sustainable development concept (Hamann \& Kapelus, 2004). In 
this context, while CSR carries on profit goals, it requires companies to improve the social and environmental impacts of their activities (Hamann, 2003). In that case, for mining corporations CSR can be defined as balancing the various demands of community or stakeholders and the necessities for environmental protection with their profit making interest (Jenkins, 2004).

At this point, the question of 'what kind of responsibilities corporations have and to which stakeholders' comes to mind (Carroll, 1991). According to stakeholder theory, answering that question in other words defining the stakeholders of the organization and perceived stakes of those stakeholders is the first step of the process of stakeholder management (Freeman, 2010). Therefore, from the perspective of stakeholder theory's assumptions responding the interests and concerns of stakeholders is crucial for mining corporations in order to develop appropriate and effective CSR policies (Mutti et al., 2012).

In the light of above mentioned statements, this study is based on the assumptions of stakeholder theory (Freeman, 2010) and aims to develop a CSR framework for mining sector and put forward the differences in the CSR perception and interests of the main stakeholders in mining sector, which are defined as government, mining corporations, and other social stakeholders as a result of literature review. (Note 1) In defining the CSR activity criteria, Yakovleva and Vazquez-Brust's (2012) study, which adopts Carroll (1991) and Visser's (2008) models, is referenced in addition to the interviews conducted with key stakeholders. The criteria that stand for economic, legal, ethical, philanthropic and environmental dimensions of CSR are used. Also, the Analytic Network Process (ANP), which is a decision making technique with multiple criteria, is used in measuring the criteria to be able to bring out how stakeholders perceive CSR activities of mining corporations and which activities they attach more importance and priority. In this regard, this study makes two important contributions to the CSR literature:

1) The examples addressed in detail in the literature review show that the conflicts in mining sector, whether in Turkey or in other countries, basically stem from the difference in perspectives and interests of main stakeholders in matter of CSR. At the same time, Yakovleva and Vazquez-Brust (2012) claim that the perception of CSR differentiates according to region and culture. They state that different cultures bring up different values and these values shape the society's expectations from corporations and the role of corporations in society mutually. Accordingly, from the aspect of stakeholder theory understanding the priorities and interests of the stakeholders in mining sector is highly important for mining corporations in order to understand the expectations of other stakeholders they face. In addition, it is crucial so as to comprehend social movements and conflicts arisen among actors in mining sector.

2) Although the previous studies in CSR research on mining sector (e.g. Kapelus, 2002; Hamann, 2004; Hamann \& Kapelus, 2004; Jenkins, 2004; Jenkins \& Yakovleva, 2006) and on the differences of stakeholders' perceptions and expectations within stakeholder perspective (e.g. Cragg \& Greenbaum, 2002; Yakovleva \& Vazquez-Brust, 2012; Mutti et al., 2012) have made large contributions to the topic, it is noticeable that in those case studies interview and content analysis methods have been generally used within the qualitative methodology. There is no study found in reviewed literature that weights the perceptions and expectations of stakeholders in mining sector by using an analytical method such as ANP.

\subsection{Corporate Social Responsibility and Stakeholder Theory}

The concept of CSR has been defined in many ways since after its appearance in modern literature in 1950s and started to be related with alternative themes such as corporate social performance, stakeholder theory, and business ethics theory, especially after 1980s (Carroll, 1999). (Note 2) In this process, it is noticeable that there has been no agreement upon the definitions of corporates' being responsible in a social manner (Carroll, 1991) and the notion of CSR (Carroll, 1979). Although there is still a lack of consensus, Carroll's (1979) definition has been accepted and used prevalently (Boulouta \& Pitelis, 2014). In that definition, Carroll (1979, p. 500) states CSR as "the economic, legal, ethical, and discretionary expectations that society has of organizations at a given point in time".

Carroll $(1979,1991)$ has conceptualized the dimensions of CSR in a form of pyramid. The economic responsibilities that form the bottom of the pyramid are based on gaining profit by producing and selling the goods society needs. Legal and ethical responsibilities lie respectively above the economic responsibilities. Legal responsibilities refer to the obedience to legal requirements, and ethical responsibilities refer to meeting the standards, norms, and expectations beyond regulations while considering public relations. At the top of the pyramid, there are philanthropic (discretionary) responsibilities, which stands for corporations' charitable activities, contribution to society and so that being considered as good corporate citizen by society (Carroll, 1979; Carroll, 1991). In the model, the economic and legal responsibilities are characterized as required, ethical 
responsibilities as expected and philanthropic responsibilities as desired (Schwartz \& Carroll, 2003).

It is noteworthy that environmental responsibilities are not highlighted as a separate dimension in the model. In their study on mining sector, Yakovleva and Vazquez-Brust (2012) claim that Carroll (1991) places environmental responsibilities between legal and ethical dimensions, which can be changeable in developing countries while being applicable in developed countries; therefore, environmental responsibilities may be placed between ethical and voluntary dimensions since the regulative climate is weaker in developing countries. On the other hand, when it comes to sectors like mining, which have significant environmental impacts (Urkidi, 2010) those impacts are discussed as much as social effects (e.g Jenkins, 2004). In this respect, Yakovleva and Vazquez-Brust (2012) stress the distinctive importance of environmental issues among the other dimensions and add environmental responsibilities to Carroll's (1991) pyramid as a separate dimension.

While building a conceptual framework, the current study bases on Yakovleva and Vazquez-Brust's (2012) paper which adopts Carroll (1991) and Visser's (2008) models; and economic, legal, ethical, philanthropic and environmental dimensions are used in the study. Together with these studies, the stakeholders' opinions received with a field study are used while identifying the criteria of these dimensions.

One of the most noticeable things in the historical development of the CSR is that there is an evolution of the earlier idea of corporates' being only responsible to their shareholders in terms of profit, into meeting also the expectations of other stakeholders (Carroll, 1991). In this sense, the stakeholder theory constitutes a substantial conceptual background for the concept of CSR (McWilliams \& Siegel, 2001; Donaldson \& Preston, 1995).

The term stakeholder is used to refer to the groups that affect the achievement of organizational goals or affected from the achievement of organizational goals (Freeman, 2010). This definition places the interests of stakeholders into a special position. The resources and contributions that are provided by stakeholder groups, which have different rights, goals, expectations, and responsibilities within a system of complicated relations, are important for companies' success and survival (Mutti et al., 2012). Stakeholder theories propose that managers' responsibility is not only maximizing shareholder value, as agency theory points out, but also taking into consideration the well being of other stakeholders affected by corporate decisions (Cragg \& Greenbaum, 2002). At this point, stating that there is a natural harmony between stakeholders and CSR, Carroll (1991) defines stakeholder management as a win-win relationship that managers harmonize their own goals with stakeholders' demands and expectations. Within the frame of this relationship, the meaning of CSR for mining corporations is to bring into balance the differentiating interests of society, the obligation of environmental protection, and profit goals; then, shaping their relations, attitudes, and strategies in accordance with that balance (Jenkins, 2004).

\subsection{Differences in Approaches to Mining Sector and CSR}

Although CSR aspect of mining companies has been getting a considerable amount of attention and spotlight (Hamann, 2004), it is quite hard to say that the sector has a good prominence of CSR (Hamann \& Kapelus, 2004). Underlying causes of that negative image, there are criticisms about mining companies that they are insensitive about environmental and social impacts of their operations; they operate in areas without social legitimacy; and they not only deplete economically valuable resources but also cause severe damage in the areas they operate (Jenkins, 2004).

In addition, the criticisms are not limited with companies' home countries. With the developments in global economy and the effects of globalization, multinational companies that want to benefit from resources in different countries have extended their borders towards those countries; and so, their social and environmental impacts (Ozen \& Ozen, 2009). As an example of that process, mining companies have started benefiting from the liberalizing tendencies in the global economy by shifting their operations from developed countries, where resources are getting scarce, to developing countries (Kapelus, 2002). With liberal tendencies, new operating opportunities have been opened up in areas that were legally closed because of political restrictions, and this is one of the most important contributions of those tendencies to mining companies (Bridge, 2004). However, the power provided by liberal policies also creates new initiatives that challenge multinational mining companies in terms of their responsibilities to communities affected by their business activities (Shamir, 2004).

These criticisms about environmental and social impacts are responded with globally determinant rhetoric of "free market capitalism" and "neoliberalism" (Jenkins, 2004, p. 26). Dumenil and Levy (2005, p. 9) states that "neoliberalism is often described as the ideology of market and private interests as opposed to state intervention". According to Friedman, the basis of this logic can be explained with the thesis of "elementary proposition that both parties to an economic transaction benefit from it provided the transaction is bilaterally voluntary and informed" (Friedman 1962, p. 55 as cited in Clarke, 2005, p. 50). According to this, since mining activities are in favour of everyone, collective structures such as state or other communities should not interfere with the free 
development of mining operations (Jenkins, 2004). Then, the trade-off between the development opportunities and impacts of mining activities can be related to how much wealth generated, how that wealth is distributed, and what 'socio-ecologic' costs are assumed because of mining operations (Emel \& Huber, 2008).

This cost-benefit relationship defined put forwards the idea that if mining companies' financial contributions overweigh their environmental damages, then those damages can be tolerated up to an extend (Jenkins, 2004, p. 24). When those benefits arise, liberalization requires-in a sense-the relinquishment of state constraints on environmental conservation, food safety and public health (Hartwick \& Peet, 2003). At the same time, by using the economic and political power gained from trade liberalization, multinational companies play an active role in operated country's government decisions about abandoning restrictive state policies, legal measures, social reforms and employment rules, environmental, social, and civil rights (Shamir, 2004).

Questioned in parallel with this neoliberal rhetoric, relationship between commercial activities and environment is described by World Trade Organization as a win-win strategy and it is implied that the economic growth controlled by trade liberalization will guarantee better policies both on trade and environment (Hartwick \& Peet, 2003). From a similar perspective, World Bank policies also support the idea that both mining companies and host countries would benefit from direct investments; while companies make profit, local community is employed and state generates revenues via licenses and taxes, and widespread social benefits can be obtained with distribution of these revenues to social development programs, such as health, education, and infrastructure (Emel \& Huber, 2008).

Herein, companies' attitudes towards CSR should be considered within a relation with state's stance and corporate environment. In his case study of four platinum and two chromium mines, Hamann (2004) puts forward that regarding their CSR practice and motivation, mining companies are affected by the institutional environment and changes in this environment which state is central. However, especially in developing countries, state's priority is generally promoting the industrial development process in order to attract investments that create employment and revenue (Hamann, 2003). As a result, in many countries, there are neoliberal rhetoric that emphasizes the importance of mining activities and foreign investment for state economy and there are more flexible and less environmentally sensitive regulations, as in the case of Turkey (Ozen \& Ozen, 2009).

A similar example is highlighted in Holden and Jacobson's (2007) case study of Philippine that the government provided legal allowances to mining companies along with the implementation of state supported neoliberal economy policy, which aimed to attract foreign investment. In parallel with those statements, the perception that mining activities are beneficial to national interests and the possible impacts of mining activities on communities generally accompany each other (Hamann, 2003).

Those neoliberal rhetoric and practices have not been sufficient to dispel concerns about negative effects of mining activities. On the contrary, the human rights issues and environmental damage that mining caused in many countries have resulted in growing public concerns about social responsibility dimensions of mining activities (Warhurst, 2001, as cited in Hamann, 2003). Besides, it is underlined that the environmental and social impacts of metal mining and more specifically gold mining have reached a crucial level with the implementation of new and riskier technologies (Urkidi, 2010). For example, although technologies like "cyanide leaching method", which is used in gold dissolution, enable profitable operation of low grade ore deposits (Urkidi \& Walter, 2011), it is claimed that this method has negative effects such as high water consumption and acidification (Urkidi, 2010).

In addition to environmental concerns, the interaction between the notions of sustainable development, economic growth, environmental deterioration, and social justice occupy a large place in discussions of mining activities (Mutti et al., 2012). In this context, from the point of mining sector, the concept of sustainable development is based on economic development, environmental preservation, and social integrity dimensions (Jenkins \& Yakovleva, 2006).

Stern (1995) defines the concept of sustainability as "development that will give future generations opportunities equal to or greater than those of the present generation" (p. 53), and based on econometric analysis conducted upon 19 non-OPEC (Organization of the Petroleum Exporting Countries) developing countries, he concludes that the hypothesis of "the mining sector detracts from sustainability in developing countries" cannot be rejected except for some countries (p. 61). Without a doubt, a claim like this should be considered depending on how the issue of sustainability is approached. In contrast with the view that the consumption of natural capital means an increase in economic and social capital for future generations, a stronger major approach argues that since other types of capital cannot be an alternative of natural capital, mining companies have negative effects in terms of sustainability (Mutti et al., 2012). 
As a part of concerns about mining, Hamann (2003) argues that getting society's approval is a complicated and problematic identification process and he exemplify his claim with Wavecrest mine in Eastern Cape, South Africa. In Wavecrest case, the study results that the group who opposed mining activities most was the elderly males who had the strongest authority in the community. While that group opposed to the mine with concerns such as losing lands, changes in lifestyle, and lessened authority in community, the youth and women were more positive about the mine with the hope of positive results such as creation of new jobs and therefore a decrease in migration (Hamann, 2003). Considered within this framework, it can be said that the underlying reason of an environmental disagreement is the opposing evaluations of different social actors (Urkidi, 2010).

The literature summarized in so far argues that the state, mining companies, and related social actors, who are the parties of the discussion regarding the issue of mining activities, have different perspectives about the presence of mining companies and the results of their activities. Both the environmental-social concerns and the differences in evaluating the results of mining activities create a conflict environment among related groups. On the side of social actors, opponent views take a great space on the arguments. Mining companies are exposed to considerable amount of pressure from opponent groups especially in developing countries (Kapelus, 2002). In this regard, prominent researchers have conducted studies in some of those countries, such as South Africa (Kapelus, 2002); Chili (Urkidi, 2010; Urkidi \& Walter, 2011); Argentina (Urkidi \& Walter, 2011; Mutti et al., 2012), Indonesia (Jenkins, 2004). These studies discuss the opponent views, conflicts in different contents and levels, social movements and protests, and the results of these pressures for mining companies.

Humphreys (2000) states that community relations are strategically important for mining companies in terms of facing probable high costs of those above-mentioned activist actions and providing competitive advantage in the sector. The CSR concept offers a quite useful conceptual framework to address companies' attitudes towards various stakeholders (Wheeler, Fabic, \& Boele, 2002). At his point, mining companies answer the increasing and spreading criticisms over their activities with formulated CSR policy and strategies (Jenkins, 2004; also Kapelus, 2002).

In order to secure their existence, get necessary operation licenses, and get access to other resources mining companies have to pay attention to documenting or reporting their environmental and social performance (Peck \& Sinding, 2003). Highlighting the importance of CSR activities for mining companies some researchers (e.g. Jenkins, 2004; Jenkins \& Yakovleva, 2006) have analysed expressions related with CSR in corporations' annual reports, sustainability reports, and social and environmental reports. Within the scope of these studies, it can be claimed that regarding survival of corporations it is also important how different stakeholders perceive the environmental and social results of mining activities.

However, it can be said that in many cases, the CSR strategies are not enough to prevent reactions of stakeholder groups or mining companies are not considered as well intentioned as they claim they are. In her study taking the examples of mines in Indonesia (PT Kelian Equatorial Mining) and Australia (Jabiluka Mine), Jenkins (2004) puts forward that mining companies face very complicated social and environmental issues in their operations and that makes it more difficult to solve possible conflicts with local communities. The study results that compensation strategies, community funds and development projects do not produce expected effects in terms of cooling the social pressures down because of multiple and conflicting demands and community development projects are perceived as community controlling activities rather than social responsibility. Additionally, as a result of their case study on mines in South Africa and Zambia, Hamann and Kapelus (2004) state that there is an important gap between mining companies' CSR activities and "accountability and fairness" criteria which refer to the responsibility of companies from their direct and indirect impacts and forming their CSR activities beneficial to the most vulnerable or worst off.

Mutti et al. (2012) explain the differences in perceptions and expectations of stakeholders regarding mining companies' CSR activities by stakeholder theory, and support their assumptions with structured interviews conducted in two different regions of Argentina. According to their study results from the perspective of mining industry network, companies view CSR as a major element for conservation of social licences and co-existence with local community despite the emphasis on voluntary and social dimensions. Similarly, analysing the environmental and social responsibility statements in 16 mining companies' reports within the context of the use of language and structure, Jenkins $(2004$, p. 32) concludes that companies' social strategy decisions can be characterized as a strategic reaction to possible challenges from the community they operate, rather than a moral choice. At this point, another issue is the companies' search of "reputation", which is deemed as important responding to reactions. Mining companies with good reputation may have a greater performance thanks to improved relations with community and employees at local project level, and easier access to financial resources and other permits at international level (Hamann, 2003). 
These prognoses are understood better when considered within the assumptions of stakeholder theory, which binds corporates' performance to taking account of various stakeholders carefully (Freeman, 2010). At his point, Kapelus (2002) asserts that having good relations with local communities, that are directly and negatively affected from mining activities, have special importance within companies' CSR programs. Then, building those "good relations" becomes more of an issue. In this context, approaching the CSR activities from the perspective of stakeholder theory, Cragg and Greenbaum (2002) put forward how managers evaluate companies' responsibilities to stakeholders in their case study research on British Colombia. In the study, interviewed managers define their company priority as showing respect to stakeholders' interests such as physical health, wealth, comfort, and convenience. In addition, those managers see company's responsibility as not damaging local communities and their future development opportunities; not as an obligation of actively contributing to development and welfare (Cragg \& Greenbaum, 2002). Drawing similar conclusions Kapelus (2002) brings forward that mining companies tend to claim that local communities benefit from their mining activities or the negative impacts on these communities are curbed.

In Mutti et al.'s (2012) study the differentiating interests and expectations attract attention also from the perspective of institutional and social networks. Regarding CSR, the study points out that institutional stakeholders emphasise their expectations of complying with laws, paying taxes, supporting local industry; despite not being against mining companies' social contributions in principle, government authorities do not perceive CSR activities as their prior responsibilities. Furthermore, authorities do not concern about multinational corporations' environmental effects since they assume that companies show strict sensitivity as a requirement of their international environment licences (Mutti et al., 2012). It can be said that governments' attitute is decisive on CSR rhetoric of mining companies. For example, Tilt and Symes (1999) put forward that "the rehabilitation of mining sites" is situated on the top of the rhetoric about the environment in the annual reports of the Australian mining companies (p. 138). At this point, the question that comes to mind is: What are the expectations of other stakeholders on environment? From the perspective of social stakeholders, which is the third stakeholder network defined in Mutti et al.'s (2012) study, environmental issues constitute the primary responsibilities of mining companies despite the fact that civil society groups trust neither government nor corporations with the management of environmental, social, and economic impacts of mining activities. According to those groups, mining companies must not put the local community welfare in danger and it is important to evaluate CSR activities and corporate social operations in terms of suitability, usefulness, and long-term effects (Mutti et al., 2012).

Yakovleva and Vazquez-Brust (2012) conduct a similar important study in Argentina that covers the differences in the perspectives of stakeholders. In their study, although some similarities are identified between government and mining industry, responsibilities that most emphasised by government are the economic and legal ones while environmental and philanthropic responsibilities are the least emphasised. According to the study, economic dimension is also the most emphasised dimension by mining companies, company headquarters, and international financial organisations; on the contrary, civil society puts the most of its emphasis on environmental and ethical responsibilities while considering philanthropic and legal responsibilities as least important.

Evaluating literature within the scope of stakeholder theory, it can be summarized that stakeholders in mining sector are mining companies, government, and other social stakeholders (e.g. civil society and local competitors). Although these stakeholders are sometimes aligned with each other, they have different perspectives and interests.

\subsection{Mining in Turkey and Social Movements Against Mining Operations}

Becoming more important with the rising trend in gold prices gold prospecting operations have gained speed in parallel with changes in Mining Law and developments in technologies, and consequently have increased the gold potential of Turkey (Koza Gold, 2014). According to Mineral Research \& Exploration General Directorate (MTA) data, Turkey has 700 tons (proven + probable) total gold reserves by year 2013. Considering this reserves in terms of gold mineralisation areas there are nine gold and silver deposits, namely Havran (Kucukdere), Balikesir; Ovacik, Bergama; Efemcukuru, Izmir; Sart, Manisa; Kisladag, Usak; Kaymaz, Eskisehir; Ilıc (Copler), Erzincan; Cerattepe, Artvin; and Mastra, Gumushane (www.mta.gov.tr).

In Turkey, developments in gold extracting and processing have gained momentum since 1980s and the legislation permitting foreign-invested companies to prospect and extract gold was regulated in 1985 (Sertkaya Dogan, 2005). Appearing because of the liberalisation process after 1980s, these regulations resulted in adoption of neoliberal policies in mining sector likewise others (Ozen \& Ozen, 2010). In parallel with these developments, three domestic (including Etibank and Yurttaslar Mining) and seven foreign companies got prospecting and 
extraction licences (Sertkaya Dogan, 2005). In parallel with changing regulations in legislative framework and increasing number of foreign companies, several social movements and protests against mining activities became a hot topic in Turkey (e.g. Coban, 2004; Ozen, 2009a, 2009b; Ozen \& Ozen, 2009, 2010, 2011). These social movements that appeared in areas such as Bergama, Izmir; Esme, Usak; Efemcukuru, Izmir; Balikesir; and Canakkale (Ozen \& Ozen, 2010). Among them, the most widespread and long lasting protest was "ecological resistance movement" which was against multinational Eurogold's mining operations in Bergama, Izmir (Coban, 2004, p. 438).

In the first stage, the movement had been built upon the rhetoric of environmental protection and anti-imperialism and then it acquired a wider dimension afterwards. (Note 3) In terms of environmental criticisms, specifically the usage of cyanide was voiced and the hazardous effects of cyanide and other heavy metals in tailings impoundments upon public health and environment were pointed out. On the other hand, anti-imperialist criticisms emphasised that as a foreign company Eurogold had been operating in different areas of Turkey without paying attention to public health and environment and had the intention of exploiting Turkey's natural resources (Ozen, 2009a, 2009b).

Regarding this movement, Ozen and Ozen (2010) state that there is a two-way relationship between public policies and social movements; on the one hand, public policies cause social movements, on the other hand those social movements bring about developments in social policies. However, it can be said that Turkish government took a neoliberal stance particularly in Bergama movement (Ozen \& Ozen, 2011). Evaluating the Bergama protest movement, Coban (2004) supports this view and points that local communities' reactions were mostly environmental; nevertheless, the government took a stance in favour of mining companies and mining operations with the motivation of increasing economic growth and social welfare by attracting foreign investments. Ignoring rulings, the government issued new licences while law-enforcement officers were responding to protests harshly, which created a front against the movement and became an important factor in weakening the protests (Ozen, 2009a, 2009b). Then, it can be stated that the government was sided with a supporting coalition formed by some mining companies, state authorities, journalists, politicians, and academicians in order to provide the continuance of mining operations and make the entry of foreign investment easier (Ozen \& Ozen, 2010).

At the end of the process in 2004, the new Mining Law was enacted, which gave mining companies a ground to keep their contradictive operations, restructured the legal framework of mining and have made Turkey more attractive for foreign investors (Ozen, 2009a, 2009b). This law not only opened the protected areas such as olive groves, natural parks, and historic districts to mining, but also made pre-operational environmental impact assessment non-obligatory and provided mining companies tax advantages and guaranteed the given licences (Ozen, 2009a, 2009b). This legislative change is important in terms of being a consequence of conflicts between Bergama protesters, a multinational mining company and government (Ozen \& Ozen, 2009).

In Bergama example, these developments give us significant information about how that social movement influenced the form of state policy (Ozen \& Ozen, 2010) and how gold mining industry is restructured in Turkey (Ozen \& Ozen, 2009). In sum, mining is a controversial topic in Turkey, as it is in many other countries. Gold mining has been discussed among the stakeholders including the government within the context of its environmental and social impacts as well as its economic benefits, but no settlement has been reached. At this point, the overall evaluation of Turkey, that the stakeholders have different perspectives and expectations, is in parallel with the arguments in the literature.

\section{Method}

Both the previous literature and the stakeholders' opinions (i.e. knowledge, experience, and discernment) are important when identifying corporate social responsibility criteria that should be taken into consideration in mining sector. In this sense, aiming to reveal the differences of stakeholders' perceptions and expectations regarding CSR, in this study the Analytic Network Process (ANP), which is a multiple-criteria decision making technique, is applied to identify CSR criteria in mining sector. Decision problems with a complexity among criteria are named as multiple-criteria decision making problems (Goktolga \& Gokalp, 2012). Mostly, there are imponderability and incommensurability among the criteria in complex decision making problems (Urfalioglu \& Genc, 2013). Analytic Hierarchy Process (AHP) method, which is a multiple-criteria decision making technique that enables identifying the levels of significance of criteria by pairwise comparisons, is frequently used in the literature in order to remove this complexity (Gungor \& Isler, 2005).

Developed by Thomas L. Saaty, AHP enables the evaluation of qualitative and quantitative factors together, and includes decision makers' knowledge, experience, and discernments into the decision making process (Chen \& 
Wang, 2010). Since the AHP had been criticised because it models problems in a hierarchical structure, later, the ANP method was developed by Thomas L. Saaty, with the thought that the situation is not that simple in real life (Saaty \& Shih, 2009). ANP is an improved version of AHP (Niemira \& Saaty, 2004) within which decision making problems modelled in a form of network, as well as internal and external dependence relations and feedbacks are taken into consideration (Hsu, Hung, \& Tang, 2012). In this way, ANP provides more realistic decisions since it enables modelling of complex problems that could not be modelled within a hierarchical structure (Karsak, Sozer, \& Alptekin, 2002) (See Figure 1).

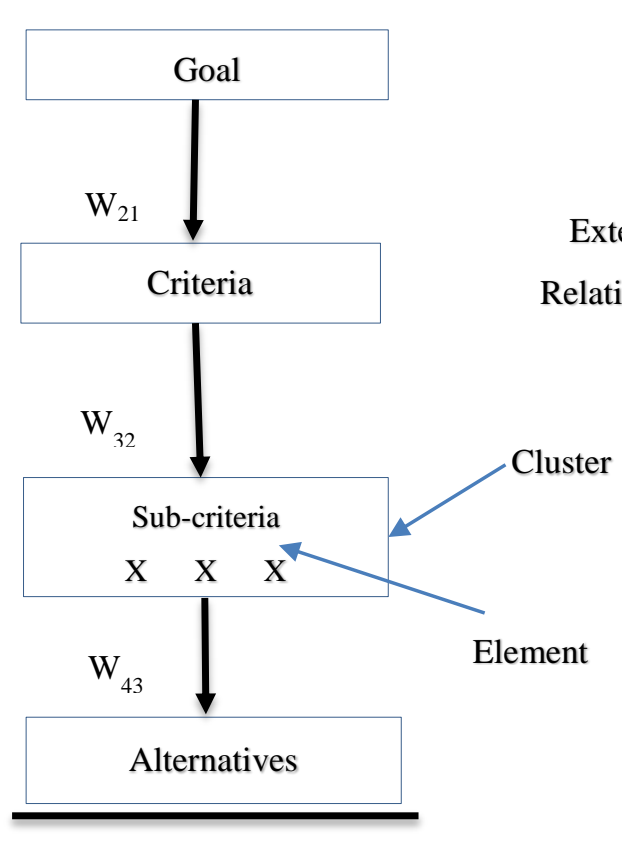

AHP Structure

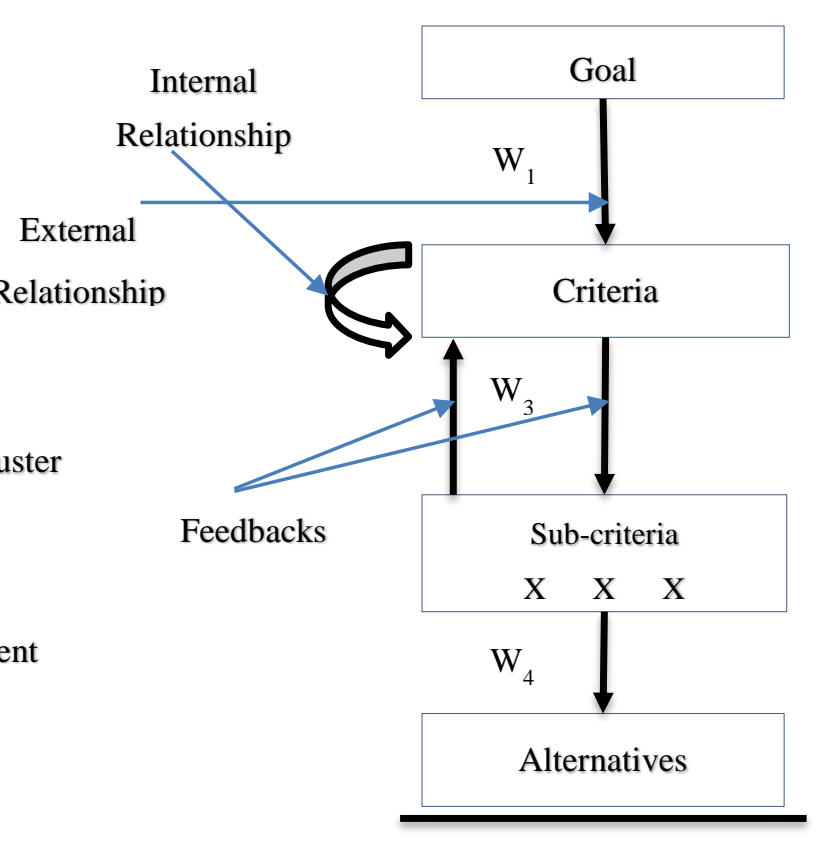

ANP Structure

Figure 1. AHP and ANP structures (Source: Zaim, Sevkli, Akdağ, Demirel, Yayla, \& Delen, 2014).

\subsection{Research Design}

Since the problem of identifying corporate social responsibility criteria in mining sector is a decision making problem that contains relations in-group and between groups, in this study the ANP method is preferred. Stages of the method are as follows (Niemira \& Saaty, 2004; Saaty, 2009; Zaim et al., 2014; Chang, Liao, Tseng, \& Liao, 2015):

a. Identifying the problem and constructing the network model: At this stage (a) the problem is identified, (b) related criteria, sub-criteria, and alternatives are identified, (c) the matrix of relations, that shows the dependencies between criteria, is constructed, and (4) based on the matrix the network model is constructed.

b. Constructing the unweighted supermatrix: Binary relations seen in the matrix of relations in the network model are evaluated by significance scale developed by Saaty (See Table 1). After, the unweighted supermatrix that contains all binary relations is constructed.

c. Constructing the weighted supermatrix: Values of the unweighted supermatrix are multiplied by the weight of main criterion which sub-criterion falls into, and the weighted supermatrix is constructed.

d. Constructing the limit supermatrix: At this stage, model variables are multiplied by itself until all rows of the weighted supermatrix have the same value. This matrix provides importance weights of criteria and sub-criteria. 
Table 1. Importance scale (Source: Niemira \& Saaty, 2004)

\begin{tabular}{|c|c|c|}
\hline & Definition & Explanation \\
\hline 1 & Equal importance & Two activities contribute equally to the objective \\
\hline 2 & Weak & \multirow{2}{*}{ Experience and judgment slightly favour one activity over another } \\
\hline 3 & Moderate importance & \\
\hline 4 & Moderate plus & \multirow{2}{*}{ Experience and judgment strongly favour one activity over another } \\
\hline 5 & Strong importance & \\
\hline 6 & Strong plus & \multirow{2}{*}{$\begin{array}{l}\text { An activity is favoured very strongly over another; its dominance } \\
\text { demonstrated in practice }\end{array}$} \\
\hline 7 & Very strong or demonstrated importance & \\
\hline 8 & Very very strong & \multirow{2}{*}{$\begin{array}{l}\text { The evidence favouring one activity over another is of the highest possible } \\
\text { order of affirmation a reasonable assumption }\end{array}$} \\
\hline 9 & Extreme importance & \\
\hline $\begin{array}{l}\text { Reciprocals of } \\
\text { above }\end{array}$ & \multicolumn{2}{|c|}{$\begin{array}{l}\text { If activity } \mathrm{i} \text { has one of the above nonzero numbers assigned to it when compared with activity } \mathrm{j} \text {, then } \mathrm{j} \text { has the } \\
\text { reciprocal value when compared with I }\end{array}$} \\
\hline
\end{tabular}

\subsection{Implementation}

The research is conducted in Gumushane (means "house of silver") Province, Turkey, which has a rich mining background. Gumushane is highly important for Turkish mining industry in that along with other mines the city has several gold deposits and an important potencial in terms of ores such as gold and silver (Vural et al., 2013; Mineral Research \& Exploration General Directorate [MTA], 2010). In the city, there are a number of small enterprises in different branches of mining and three active very large mining companies (Vural et al, 2013).

At the first stage, decision problem was defined as identification of CSR criteria in mining sector and differences in stakeholders' expectations. In the process of identifying, based on Mutti et al.'s (2012) study and opinions of specialists, firstly, the stakeholders were grouped as government, mining companies, and other social stakeholders and interviews were conducted with key stakeholders within these groups (See Table 2). Pairwise comparison values entered to Superdecision software and Limit Supermatrix was calculated. On the other hand, to evaluate the subjectivity of decision makers consistency index was calculated. To ensure consistency the the index is expected to be smaller than 0.10 (Oztaysi, 2014); otherwise decision makers should revise their judgements. Results obtained shows that consistency index ratio is smaller than 0.10 . It can be stated that using face-to-face interview method has an effect on the results.

Table 2. List of interviews with stakeholders in mining sector

\begin{tabular}{llll}
\hline \multicolumn{1}{c}{ Government } & Mining Companies & \multicolumn{1}{c}{ Other Social Stakeholders } \\
\hline - $\begin{array}{l}\text { Provincial Directorate of State Hydraulic } \\
\text { Works (1 Engineer) }\end{array}$ & $\begin{array}{l}\text { Three mining companies that } \\
\text { operate in several cities in }\end{array}$ & $\begin{array}{l}\text { - Non-governmental Organizations } \\
\text { (Environment Association, The Turkish }\end{array}$ \\
- Provincial Directorate of Ministry of & Turkey (1 manager/ & Foundation for Combating Soil Erosion, \\
Environment and Urbanization (1 Manager) & representative from each & for Reforestation and the Protection of \\
- $\begin{array}{l}\text { Provincial Directorate of Public Health } \\
\text { Institution (1 Doctor) }\end{array}$ & & Natural Habitats) \\
- Revenue Office (1 Specialist) & & - Academicians (3 Academicians) \\
- Social Security Institution (1 Specialist) & & living in mining areas) \\
- Regional Directorate of Forestry & & \\
\hline
\end{tabular}

Secondly, based on prominent literature (i.e. Yakovleva \& Vazquez-Brust, 2012; Carroll, 1991; Viser, 2008) and opinions of stakeholders interviewed, the main criteria and sub criteria for each main criterion were defined (See Table 3) by specialised academician group. (Note 4) In the next stage based on identified relationships among criteria the matrix of relations and the network model was constructed as shown in Figure 2. 
Table 3. The CSR criteria framework that can be applicable to mining sector

\begin{tabular}{|c|c|c|}
\hline Main Criteria & Sub Criteria & Keywords Obtained from Stakeholder Opinions \\
\hline \multirow{4}{*}{$\begin{array}{l}\text { Economic } \\
\text { Criteria } \\
\text { (C1) }\end{array}$} & $\begin{array}{l}\text { To create employment }{ }^{2,3,4} \text { and invest in human } \\
\text { capital }^{2,4}\left(\mathrm{C}_{11}\right)\end{array}$ & $\begin{array}{l}\text { To provide jobs, train qualified personnel, bring occupations for } \\
\text { people by giving priority to local community }\end{array}$ \\
\hline & $\begin{array}{l}\text { To contribute to the economy }{ }^{2,3,4} \text { through } \\
\text { payments to the state }{ }^{2,3,4}\left(\mathrm{C}_{12}\right)\end{array}$ & Tax and usufruct payments to the state. \\
\hline & $\begin{array}{l}\text { To stimulate the local market }{ }^{2,4} \text { and to prevent } \\
\text { migration }^{4}\left(\mathrm{C}_{13}\right)\end{array}$ & $\begin{array}{l}\text { Multiplier effect, shopping from local shops, rent vehicles from } \\
\text { local community. To prevent young population's migration to big } \\
\text { cities by creating employment. }\end{array}$ \\
\hline & Profitability $^{1,3,4} \quad\left(\mathrm{C}_{14}\right)$ & $\begin{array}{l}\text { The contribution of the company to the state economy and to itself } \\
\text { by its operations. }\end{array}$ \\
\hline \multirow{4}{*}{$\begin{array}{l}\text { Legal Criteria } \\
\text { (C2) }\end{array}$} & $\begin{array}{l}\text { To comply with the } \text { EIA }^{*} \text { report }^{4} \text { and relevant } \\
\text { legislation }{ }^{1,3,4}\left(C_{21}\right)\end{array}$ & $\begin{array}{l}\text { To ensure compliance with the standards of EIA reports and } \\
\text { regulations for waste water basins. To adapt to the premise legal } \\
\text { conditions during the inspections of the agencies. }\end{array}$ \\
\hline & To comply with occupational safety $\operatorname{law}^{4}\left(\mathrm{C}_{22}\right)$ & $\begin{array}{l}\text { To pay attention to the usage of necessary protective equipment (e.g. } \\
\text { helmet, boot, waistcoat, mask). To show sensitivity about workplace } \\
\text { safety rules. }\end{array}$ \\
\hline & Not to operate with uninsured workers ${ }^{4} \quad\left(\mathrm{C}_{23}\right)$ & Should not operate with uninsured workers. \\
\hline & $\begin{array}{l}\text { To be in communication with government } \\
\text { agency authorised in inspection }{ }^{2,3,4}\left(\mathrm{C}_{24}\right)\end{array}$ & $\begin{array}{l}\text { To be in communication with government agency officers. To } \\
\text { provide mutual feedback. To take account criticisms from } \\
\text { government agencies. }\end{array}$ \\
\hline \multirow{4}{*}{$\begin{array}{l}\text { Environmental } \\
\text { Criteria } \\
\text { (C3) }\end{array}$} & $\begin{array}{l}\text { Not to adversely affect air, water, and soil } \\
\text { components }^{3,4}\left(\mathrm{C}_{31}\right)\end{array}$ & $\begin{array}{l}\text { Not to create air pollution. To pay attention to filtering and dust } \\
\text { emission. To minimize environmental damages resulting from } \\
\text { waste water, waste water basins, and purification plants. Not to } \\
\text { damage water resources. }\end{array}$ \\
\hline & $\begin{array}{l}\text { Not to impact negatively on the social aspects }{ }^{34}, \\
\left(\mathrm{C}_{32}\right)\end{array}$ & $\begin{array}{l}\text { Not to cause destruction of roads and infrastructure. Not to harm } \\
\text { agriculture and animal husbandry. To care about recycling. Not to } \\
\text { have a negative health effect on products of food production } \\
\text { enterprises. Not to cause noise pollution (psychological effect). }\end{array}$ \\
\hline & Not to negatively impact the ecosystem ${ }^{3,4}\left(\mathrm{C}_{33}\right)$ & $\begin{array}{l}\text { Not to damage forest and vegetation. Not to damage wildlife and } \\
\text { endemic species. Not to cause climate change. }\end{array}$ \\
\hline & $\begin{array}{l}\text { To minimize the possible impacts of cyanide, } \\
\text { other chemicals and wastes on environment and } \\
\text { public health }^{3,4} \quad\left(\mathrm{C}_{34}\right)\end{array}$ & $\begin{array}{l}\text { To minimize environmental damages resulting from waste water, } \\
\text { waste water basins, and purification plants. To care about } \\
\text { recycling. }\end{array}$ \\
\hline \multirow{4}{*}{$\begin{array}{l}\text { Ethical } \\
\text { Criteria } \\
\text { (C4) }\end{array}$} & Transparency and continuous reporting ${ }^{2,3,4}\left(\mathrm{C}_{41}\right)$ & $\begin{array}{l}\text { To prepare EIA reports and disclosure the results. To be open to } \\
\text { stakeholders on activities. To arrange meeting in places accessible to } \\
\text { stakeholders. Not to engage in corruption. To be able to monitor } \\
\text { activities with cameras. To report activities continuously. }\end{array}$ \\
\hline & $\begin{array}{l}\text { To be environmentally and socially conscious } \\
\text { beyond the legal requirements }{ }^{1,2,3,4}\left(\mathrm{C}_{42}\right)\end{array}$ & $\begin{array}{l}\text { To be environmentally and socially conscious beyond the legal } \\
\text { requirements in the layout of the mining site and making } \\
\text { afforestation and landscape maintenance activities. To create } \\
\text { agricultural areas and facilitate cultivation of agricultural products } \\
\text { by local community. }\end{array}$ \\
\hline & The presence of labour unions ${ }^{4}\left(\mathrm{C}_{43}\right)$ & To protect worker rights and promote unionization. \\
\hline & Corporate governance ${ }^{2,3,4}\left(\mathrm{C}_{44}\right)$ & $\begin{array}{l}\text { Compliance with corporate governance principles, making necessary } \\
\text { notifications to stakeholders continuously. }\end{array}$ \\
\hline \multirow{5}{*}{$\begin{array}{l}\text { Philanthropic } \\
\text { Criteria } \\
\text { (C5) }\end{array}$} & To support local social services ${ }^{1,3,4}\left(\mathrm{C}_{51}\right)$ & Services in areas education, health, arts etc. \\
\hline & Social benefits for employees ${ }^{4} \quad\left(\mathrm{C}_{52}\right)$ & To provide housing and social facilities. \\
\hline & Charities for various segments of society ${ }^{1,3,4}\left(\mathrm{C}_{53}\right)$ & Scholarships, Ramadan aids, sponsorships etc. \\
\hline & $\begin{array}{l}\text { Activities aimed to eliminate poverty and } \\
\text { support local businesses }{ }^{2,3,4}\left(\mathrm{C}_{54}\right)\end{array}$ & To enhance handicrafts, silver market. \\
\hline & To contribute to city identity ${ }^{4}\left(\mathrm{C}_{55}\right)$ & The protection and restoration of historical fabric. \\
\hline${ }^{1}$ Carroll, (1991); & \multicolumn{2}{|c|}{${ }^{2}$ Visser, $(2008) ;{ }^{3}$ Yakovleva and Brust, $(2012) ;{ }^{4}$ Stakeholder opinions } \\
\hline
\end{tabular}




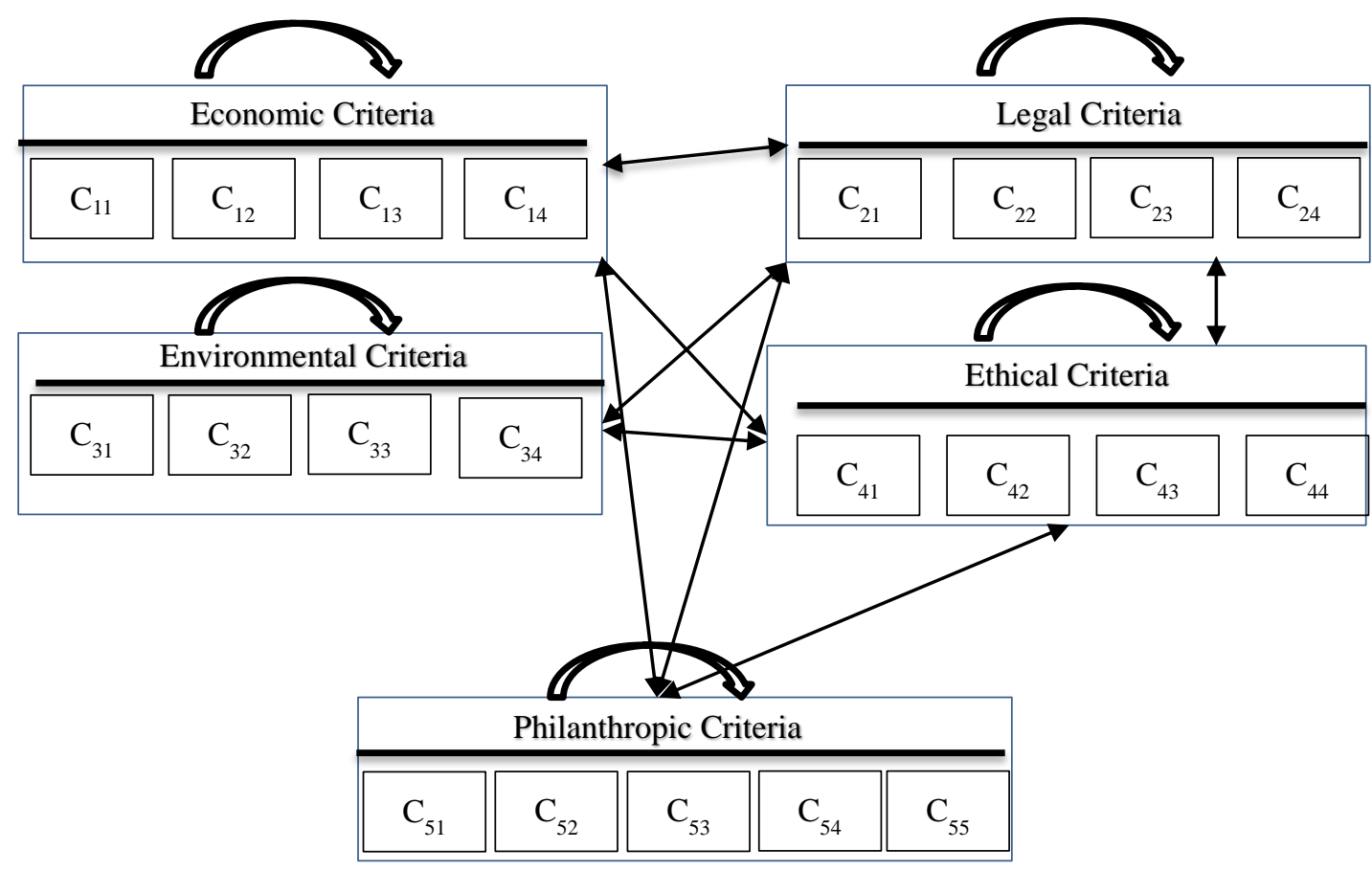

Figure 2. Network model

\section{Results}

The results for each stakeholder group are as follows:

\section{a. Government}

Legal criteria are identified as the most important criteria. Economic criteria follow legal criteria while philanthropic criteria are identified as the least important criteria. "To be in communication with government agency authorised in inspection" is identified as the most important sub criterion. On the other hand, "to contribute to city identity" is identified as the least important sub criterion.

\section{b. Mining Companies}

Economic criteria are identified as the most important criteria and followed by legal criteria. Philanthropic criteria are identified as the least important criteria. "Profitability" is identified as the most important and "to create employment and invest in human capital" is identified as the second most important sub criterion.

\section{c. Other Social Stakeholders}

Environmental criteria are identified as the most important criteria. Following, ethical criteria take the second place. "To minimize the possible impacts of cyanide, other chemicals and wastes on environment and public health" is identified as the most important sub criterion.

\section{d. All Stakeholders Combined (combined results of all stakeholders with equal weights for each)}

Main criteria are listed in descending order of importance as; legal, economic, ethical, environmental, and philanthropic. "To be in communication with government agency authorised in inspection" is identified as the most important sub criterion. "Profitability" is identified as the second most important sub criterion. Following, "To comply with the EIA report and relevant legislation" takes the third place.

Table 4 indicates the results of the priority/importance values of main and sub criteria for each stakeholder group separately and combinedly. 
Table 4. Importance levels of main and sub criteria

\begin{tabular}{|c|c|c|c|c|c|}
\hline \multirow[b]{2}{*}{ Main and Sub Criteria* } & \multicolumn{4}{|c|}{ Stakeholders } & \multirow[b]{2}{*}{$\begin{array}{l}\text { All Stakeholders } \\
\text { Combined }\end{array}$} \\
\hline & Government & $\begin{array}{l}\text { Mining } \\
\text { Companies }\end{array}$ & $\begin{array}{l}\text { Other } \\
\text { Stakeholders }\end{array}$ & Social & \\
\hline Legal Criteria (C2) & $\underline{0.456}$ & 0.263 & 0.167 & & 0.321 \\
\hline $\begin{array}{l}\text { To be in communication with } \\
\text { government agency authorised in } \\
\text { inspection }\end{array}$ & $\underline{0.138}$ & $\underline{0.098}$ & $\underline{0.11}$ & & 0.123 \\
\hline $\begin{array}{l}\text { To comply with the EIA report and } \\
\text { relevant legislation }\end{array}$ & 0.115 & 0.09 & 0.04 & & 0.090 \\
\hline $\begin{array}{l}\text { To comply with occupational safety } \\
\text { law }\end{array}$ & 0.096 & 0.044 & 0.01 & & 0.058 \\
\hline Not to operate with uninsured workers & 0.107 & 0.031 & 0.007 & & 0.052 \\
\hline Economic Criteria $\left(\mathbf{C}_{1}\right)$ & 0.245 & $\underline{0.415}$ & 0.09 & & 0.295 \\
\hline Profitability & 0.022 & $\underline{0.153}$ & $\underline{0.035}$ & & 0.096 \\
\hline $\begin{array}{l}\text { To create employment and invest in } \\
\text { human capital }\end{array}$ & $\underline{0.091}$ & 0.127 & 0.023 & & 0.087 \\
\hline $\begin{array}{l}\text { To contribute to the economy through } \\
\text { payments to the state }\end{array}$ & 0.052 & 0.073 & 0.021 & & 0.058 \\
\hline $\begin{array}{l}\text { To stimulate the local market and to } \\
\text { prevent migration }\end{array}$ & 0.08 & 0.062 & 0.011 & & 0.054 \\
\hline Ethical Criteria (C4) & 0.139 & 0.142 & 0.317 & & 0.171 \\
\hline Transparency and continuous reporting & $\underline{0.051}$ & $\underline{0.063}$ & $\underline{0.109}$ & & 0.067 \\
\hline Corporate governance & 0.038 & 0.051 & 0.097 & & 0.055 \\
\hline $\begin{array}{l}\text { To be environmentally and socially } \\
\text { conscious beyond the legal } \\
\text { requirements }\end{array}$ & 0.026 & 0.016 & 0.089 & & 0.037 \\
\hline The presence of labour unions & 0.024 & 0.012 & 0.022 & & 0.012 \\
\hline Environmental Criteria (C3) & 0.124 & 0.133 & $\underline{0.384}$ & & 0.170 \\
\hline $\begin{array}{l}\text { To minimize the possible impacts of } \\
\text { cyanide, other chemicals and wastes on } \\
\text { environment and public health }\end{array}$ & 0.032 & 0.037 & $\underline{0.158}$ & & 0.066 \\
\hline Not to negatively impact the ecosystem & $\underline{0.042}$ & 0.031 & 0.087 & & 0.046 \\
\hline $\begin{array}{l}\text { Not to adversely affect air, water, and } \\
\text { soil components }\end{array}$ & 0.028 & $\underline{0.041}$ & 0.072 & & 0.033 \\
\hline $\begin{array}{l}\text { Not to impact negatively on the social } \\
\text { aspects }\end{array}$ & 0.022 & 0.024 & 0.067 & & 0.028 \\
\hline Philanthropic Criteria (C5) & 0.034 & 0.045 & 0.041 & & 0.041 \\
\hline To support local social services & 0.01 & $\underline{0.013}$ & $\underline{0.016}$ & & 0.013 \\
\hline $\begin{array}{l}\text { Charities for various segments of } \\
\text { society }\end{array}$ & $\underline{0.011}$ & $\underline{0.013}$ & 0.013 & & 0.012 \\
\hline $\begin{array}{l}\text { Activities aimed to eliminate poverty } \\
\text { and support local businesses }\end{array}$ & 0.01 & 0.009 & 0.006 & & 0.008 \\
\hline Social benefits for employees & 0.002 & 0.006 & 0.002 & & 0.004 \\
\hline To contribute to city identity & 0.001 & 0.004 & 0.004 & & 0.003 \\
\hline
\end{tabular}

Note. * Criteria are listed according to the All Stakeholders Combined results

\section{Discussion}

The aim of this study is to identify the differences among mining sector stakeholders on CSR perceptions and expectations within the assumptions of stakeholder theory and develop a criteria framework for mining sector CSR activities. Towards this end, firstly, main stakeholder groups in mining sector are identified based on literature review. Secondly, in order to identify the criteria for CSR activities prominent literature and interviews are evaluated. Main criteria are adopted from Yakovleva and Vazquez-Brust's (2012) economic, legal, ethical, philanthropic, and environmental dimensions; sub criteria are identified with keywords from evaluated literature 
and interviews.

It is thought that determining the criteria's order of importance for different stakeholders make an important contribution for researchers and practitioners. In this sense, in order to put forward how stakeholders perceive mining companies' CSR activities and to which activities they give priority, the ANP is used to weight those criteria.

According to the results, for government agencies the most important criteria identified are legal criteria. In the literature, Mutti et al. (2012) highlight institutional stakeholders' expectations of obeying laws, paying taxes and supporting local industry in respect of CSR. Besides that, interviewed specialists from government agencies have expressed their expectation of mining companies' being in compliance with legal framework. Therefore, it can be said that current results are in parallel with previous studies and opinions of stakeholders. Other important criteria identified are economic criteria. Hamann (2003) argues that in developing countries governments' priorities are mostly employment and wealth creating investments by promoting industrial development. This argument is consistent with Ozen and Ozen's (2009) highlight of the fact that mining activities and foreign investments are important in state economy for Turkish government. Similarly, interviewed authorities have put forward their idea of necessity of activities that contribute state's economy with a minimum impact on environment. On the other hand, results show that government agencies attach the least importance to philanthropic criteria. This finding is also in accord with Mutti et al. (2012) statement that philanthropic activities are not indispensable for government authorities.

During the first interviewing process, the most stressed expectation by government authorities was that mining companies should be in a constant and efficient communication with authorized agencies. This opinion is also reflected in the results and "to be in communication with government agency authorised in inspection" is identified as the most important sub criterion. In addition, parallel with paying the least attention to philanthropic criteria, "to contribute to city identity" is found to be the least emphasized sub criterion by government agencies.

From the perspective of mining companies, analysis results show that "economic criteria" is the most important main criterion. A reflection of this finding can be seen in Yakovleva and Vazquez-Brust's (2012) study, which states that economic dimension is emphasized by mining companies and their headquarters. In parallel, managers of mining companies stated that they operate essentially to create economic benefits. Besides, they pointed out that their fundamental intention for other CSR activities is also to make profit (i.e. economic criteria). Accordingly, the finding of "profitability" sub criterion as the most important sub criterion in the analysis is an important sign of the fact that stakeholders' opinions are reflected on the results. Following, "to create employment and investment in human capital" is the second most important sub criterion for mining companies. This finding is significant since in developing countries that unemployment is an important issue, as it is in Turkey, creating jobs for local community is an important factor in gaining legitimacy as well as in keeping labour costs in a lower level.

"Legal criteria" is the second most important main criterion. In fact, company managers have stated that the main motivation of fulfilling legal requirements is to avoid monetary and operational penalties. Considering as a pyramid, economic and legal criteria are the most important criteria for mining companies, which is in parallel with Carrol's (1991) model.

From the perspective of other social stakeholders, which consists of academicians, local community, and non-governmental organizations, the results show that the main criterion of "environmental criteria" has the highest importance. In the literature, Mutti et al. (2012) state that environmental responsibilities are the primary responsibilities of mining companies emphasized by "social stakeholder" group, which is consistent with current study results. Under this main criterion "minimizing the possible impacts of cyanide, other chemicals and wastes on environment and public health" is the most important sub criterion. Considering the structure of environmental movements against mining companies in Turkey, it can be said that the starting point of those movements are environmental criticisms and the negative impact of cyanide usage on public health (Ozen, 2009a, 2009b). Besides, "ethical criteria" are the second most important criteria. Therefore, it can be stated that other social stakeholders' expectations from mining companies are environmental and social awareness along with transparency, accountability, and good corporate governance.

Finally, when we combine the results of all stakeholders with equal weights for each, main criteria are legal, economic, ethical, environmental, and philanthropic, respectively. These results are in parallel with government's priorities. For Turkey, as a developing country, the results bring to mind the idea that a potential balance between the interests of government and the mining companies has a central position in mining sector CSR framework. This kind of balance echoes with the "win-win" situation between companies' interests for profit and 
government's economic expectations (Emel \& Huber, 2008, p. 1393). In the current study, while legal and economic main criteria appear as the first two criteria for both government and mining companies, the context of their economic expectations differs between those two stakeholders. Accordingly, while "profitability" is the most important economic criterion for mining companies, the sub criterion of "to create employment and invest in human capital" comes into prominence on the side of government. Also, Hamann highlights that in developing countries "job creation and revenues" is an important government expectation in attracting foreign investment (2003, p. 248). According to our findings, while legal main criterion is the topmost priority of governments, it is mining companies' second priority. In other words, to be in accord with government's legal expectations comes in the second place for mining companies, whose fundamental motivation is profitability. Therefore, it can be interpreted that mining companies consider complying to some extent with government's legal expectations as a must that would guarantee their activities' continuation. The fact that the sub legal criteria of "to be in communication with government agency authorised in inspection" and "to comply with the EIA report and relevant legislation" both have the same priority for these stakeholder groups supports this idea. In parallel with these statements, the interviews conducted with mining companies and government agencies support the concordance and corresponding interests between these two stakeholder groups.

The current study results are important in terms of weighting the perceptions and expectations of stakeholders in mining sector by using an analytical method such as ANP. Although Yakovleva and Vazquez-Brust's (2012) study has revealed the differences of stakeholders' perceptions and expectations regarding CSR activities, their study identifies stakeholders' CSR orientations according to frequency of keywords of CSR dimensions based on data from interviews, observations, and document analyses. On the other hand, their study was insufficient in terms of revealing the comparative importance of CSR activities from the perspective of different stakeholders. In this context, the current study's main contribution to the literature is the assumption that every expectation stated by stakeholders would have different importance. Therefore, the proposed framework is considered suitable for measurement of mining sector CSR activities.

\subsection{Limitations and Further Research}

Besides its above mentioned contributions, the current study has some limitations to take into account in terms of interpreting the results. First of all, a change in the sample may also change the attributed criteria weights. Also, since confidentiality concerns are high in mining companies, there are some challenges to reach the right person and right data. Finally, the subjective perspective of the ANP method can also be considered as a limitation of current study.

On the other hand, this study can make more critical results possible in the future with the use of fuzzy logic. Also, the criteria generated in current study can be transformed into a scoring scale that can be used in CSR performance measurement of mining companies. In that way, suggestions can be made to answer the question of how to improve CSR activities of mining companies.

\section{References}

Boulouta, I., \& Pitelis, C. N. (2014). Who needs CSR? The impact of corporate social responsibility on national $\begin{array}{lllll}\text { competitiveness. Journal of Business } & \text { Ethics, }\end{array}$ http://dx.doi.org/10.1007/s10551-013-1633-2

Bridge, G. (2004). Mapping the bonanza: Geographies of mining investment in an era of neoliberal reform. The Professional Geographer, 56(3), 406-421. http://dx.doi.org/10.1111/j.0033-0124.2004.05603009

Carroll, A. B. (1979). A three-dimensional conceptual model of corporate performance. Academy of Management Review, 4(4), 497-505. http://dx.doi.org/10.5465/AMR.1979.4498296

Carroll, A. B. (1991). The pyramid of corporate social responsibility: Toward the moral management of organizational stakeholders. Business Horizons, 34, 39-48. http://dx.doi.org/10.1.1.462.4956

Carroll, A. B. (1999). Corporate social responsibility evolution of a definitional construct. Business \& Society, 38(3), 268-295. http://dx.doi.org/10.1177/0007650399.03800303

Chang, K. L., Liao, S. K., Tseng, T. Z., \& Liao, C. Y. (2015). An ANP Based TOPSIS Approach for Taiwanese Service Apartment Location Selection. Asia Pasific Management Review, 20, 49-55. http://dx.doi.org/10.1016/j.apmrv.2014.12.007

Chen, M. K., \& Wang, S. C. (2010). The Critical Factors of Success for Information Service Industry in Developing Internatonal Market: Using Analytic Hierarchy Process (AHP) Approach. Expert Systems With Applications, 37(1), 694-704. http://dx.doi.org/10.1016/j.eswa.2009.06.012 
Clarke, S. (2005). The neoliberal theory of society. In S. Alfredo, \& J. Deborah (Eds.), Neoliberalism: A Critical Reader (pp. 50-60). London: Pluto Press.

Coban A. (2004). Community-based Ecological Resistance: The Bergama Movement in Turkey. Environmental Politics, 13(2), 438-460. http://dx.doi.org/10.1080/0964401042000209658

Cragg, W., \& Greenbaum, A. (2002). Reasoning about responsibilities: Mining company managers on what stakeholders are owed. Journal of Business Ethics, 39(3), 319-335. http://dx.doi.org /10.1023/A:1016523113429

Donaldson, T., \& Preston, L. E. (1995). The stakeholder theory of the corporation: Concepts, evidence, and implications. Academy of Management Review, 20(1), 65-91. http://dx.doi.org /10.1023/A:1016523113429

Dumenil G., \& Levy, D. (2005). The Neoliberal (Counter-) Revolution. In S. Alfredo, \& J. Deborah (Eds.), Neoliberalism: A Critical Reader (pp. 9-19). London: Pluto Press.

Emel, J., \& Huber, M. T. (2008). A risky business: Mining, rent and the neoliberalization of "risk". Geoforum, 39(3), 1393-1407. http://dx.doi.org/10.1016/j.geoforum.2008.01.010

Freeman, R. E. (2010). Strategic management: A stakeholder approach. New York: Cambridge University Press.

Goktolga, Z. G., \& Gokalp, B. (2012). Is Secimini Etkileyen Kriterlerin ve Alternatiflerin AHP Metodu ile Belirlenmesi [AHP Method for Determınation of Work Affectıng The Selectioncriteria and Alternative]. Cumhuriyet University Journal of Economics and Administrative Sciences, 13(2), 71-86.

Gungor, I., \& Isler, D. B. (2005). Analitik Hiyerarsi Yaklasımı ile Otomobil Seçimi [Automobile Selection With Analytic Hierarchy Process Approach]. Uluslararası Yönetim Íktisat ve Işletme Dergisi, 1(2), 21- 33.

Hamann, R. (2003). Mining companies' role in sustainable development: The 'why' and 'how' of corporate social responsibility from a business perspective. Development Southern Africa, 20(2), 237-254. http://dx.doi.org/10.1080/03768350302957

Hamann, R. (2004). Corporate social responsibility, partnerships, and institutional change: The case of mining companies in South Africa. Natural Resources Forum, 28(4), 278-290. http://dx.doi.org/10.1111/j.1477-8947.2004.00101.x

Hamann, R., \& Kapelus, P. (2004). Corporate social responsibility in mining in Southern Africa: Fair $\begin{array}{lllll}\text { accountability or just } & \text { greenwash?. Development, } & 47(3), & \text { 85-92. }\end{array}$ http://dx.doi.org/10.1057/palgrave.development.1100056

Hartwick, E., \& Peet, R. (2003). Neoliberalism and nature: The case of the WTO. The Annals of the American Academy of Political and Social Science, 590(1), 188-211. http://dx.doi.org/10.1177/0002716203256721

Holden, W. N., \& Jacobson, R. D. (2007). Ecclesial Opposition to Nonferrous Metals Mining in the Philippines: Neoliberalism Encounters Liberation Theology. Asian Studies Review, 31(2), 133-154. http://dx.doi.org/10.1080/10357820701373291

Hsu, T. H., Hung, L. C. \& Tang, J. W. (2012). A hybrid ANP Evaluation Model for Electronic Service Quality. Applied Soft Computing, 12(1), 72-81. http://dx.doi.org/10.1016/j.asoc.2011.09.008

Humphreys, D. (2000). A business perspective on community relations in mining. Resources Policy, 26(3), 127-131. http://dx.doi.org/10.1016/S0301-4207(00)00024-6

Jenkins, H. (2004). Corporate social responsibility and the mining industry: Conflicts and constructs. Corporate Social Responsibility and Environmental Management, 11(1), 23-34. http://dx.doi.org/10.1002/csr.50

Jenkins, H., \& Yakovleva, N. (2006). Corporate social responsibility in the mining industry: Exploring trends in social and environmental disclosure. Journal of Cleaner Production, 14(3), 271-284. http://dx.doi.org/10.1016/j.jclepro.2004.10.004

Kapelus, P. (2002). Mining, corporate social responsibility and the "community": The case of Rio Tinto, Richards Bay minerals and the Mbonambi. Journal of Business Ethics, 39(3), 275-296. http://dx.doi.org/10.1023/A:1016570929359

Karsak, E. E., Sozer, S. \& Alptekin, S. E. (2002). Product Planning in Quality Function Deployment Using A Combined Analytic Network Process and Goal Programming Approach. Computers \& Industrial Engineering, 44(1), 171-190. http://dx.doi.org/10.1016/S0360-8352(02)00191-2

Koza, G. (2014). Koza Altın İşletmeleri A.Ş. Sermaye Piyasasi Kurulu’nun Tebliğine İstinaden Hazirlanmiş Yönetim Kurulu Faaliyet Raporu [Koza Gold Company 2014 Annual Report]. Retrieved from 
http://kozaaltin.com.tr/img/2014\%20-\%206M\%20T\%C3\%BCrk\%C3\%A7e.pdf

Niemira, M. P., \& Saaty, T. L. (2004). An Analytic Network Process Model for Financial-Crisis Forecasting. International Journal of Forecasting, 20(4), 573-587. http://dx.doi.org/10.1016/j.ijforecast .2003.09.013

McWilliams, A., \& Siegel, D. (2001). Corporate social responsibility: A theory of the firm perspective. Academy of Management Review, 26(1), 117-127. http://dx.doi.org/10.5465 /AMR.2001 .4011987

Mineral Research \& Exploration General Directorate [MTA] (2010). Gümüşhane İli Maden ve Enerji Kaynakları [Gumushane Province Mining Reserves]. Retrieved from http://www.mta.gov.tr/v2.0 /turkiye_maden/maden_potansiyel_2010/Gumushane_Madenler.pdf

Mutti, D., Yakovleva, N., Vazquez-Brust, D., \& Di Marco, M. H. (2012). Corporate social responsibility in the mining industry: Perspectives from stakeholder groups in Argentina. Resources Policy, 37(2), 212-222. http://dx.doi.org/10.1016/j.resourpol.2011.05.001

Ozen, H. (2009a). Located locally, disseminated nationally: The Bergama Movement. Environmental Politics, 18(3), 408-423. http://dx.doi.org/10.1080/09644010902823766

Ozen, H. (2009b). Bergama Mücadelesi: Doğuşu, Gelişimi ve Sonuçları [Bergama Movement: The Rise, Development and Results]. Attlım Üniversitesi Kütüphanesi e-Bülten, 4(14).

Ozen, S., \& Ozen, H. (2009). Peasants against MNCs and the state: The role of the Bergama struggle in the institutional construction of the gold-mining field in Turkey. Organization, 16(4), 547-573. http://dx.doi.org/10.1177/1350508409104508

Ozen, H., \& Ozen, S. (2010). Public policies and social movements: The influences of protest movements on mining policy in Turkey. Review of Public Administration, 43(2), 33-64.

Ozen, H., \& Ozen, S. (2011). Interactions in and between Strategic Action Fields A Comparative Analysis of Two Environmental Conflicts in Gold-Mining Fields in Turkey. Organization \& Environment, 24(4), 343-363. http://dx.doi.org/10.1177/1086026611426343

Oztaysi, B. (2014). A decision model for information technology selection using AHP integrated TOPSIS-Grey: The case of content management systems. Knowledge-Based Systems, 70, 44-54. http://dx.doi.org/10.1016/j.knosys.2014.02.010

Peck, P., \& Sinding, K. (2003). Environmental and social disclosure and data richness in the mining industry. Business Strategy and the Environment, 12(3), 131-146. http://dx.doi.org/10.1002/bse.358

Saaty, T. L. (2009). Applications of Analytic Network Process in Entertainment. Iranian Journal of Operations Research, 1(2), 41-55.

Saaty T. L., \& Shıh, H. S. (2009). Structures in Decision Making: On The Subjective Geometry of Hierarchies and Networks. European Journal of Operational Research, 199(3), 867-872. http://dx.doi.org/10.1016/j.ejor.2009.01.064

Schwartz, M. S., \& Carroll, A. B. (2003). Corporate social responsibility: A three-domain approach. Business Ethics Quarterly, 13(4), 503-530. http://dx.doi.org/10.5840/beq200313435

Sertkaya, D. O. (2005). Türkiye'de Altın Madenciliği [Gold Mining in Turkey]. İstanbul Üniversitesi Edebiyat Fakültesi Coğrafya Bölümü Coğrafya Dergisi, 13, 150-157.

Shamir, R. (2004). The de-radicalization of corporate social responsibility. Critical Sociology, 30(3), 669-689. http://dx.doi.org/10.1163/1569163042119831

Silberhorn, D., \& Warren, R. C. (2007). Defining corporate social responsibility: A view from big companies in Germany and the UK. European Business Review, 19(5), 352-372. http://dx.doi.org/10.1108/09555340710818950

Stern, D. I. (1995). The contribution of the mining sector to sustainability in developing countries. Ecological Economics, 13(1), 53-63. http://dx.doi.org/10.1016/0921-8009(94)00057-3

Tilt, C. A., \& Symes, C. F. (1999). Environmental Disclosure by Australian Mining Companies: Environmental Conscience or Commercial Reality? Accounting Forum, 23(2), 137-154. http://dx.doi.org /10.1111/1467-6303.00008

Urfalıglu, F., \& Genc, T. (2013). Çok Kriterli Karar Verme Teknikleri ile Türkiye'nin Ekonomik Performansının Avrupa Birliği Üye Ülkeleri ile Karşılaştııılması [Comparison Of The Economic 
Performance Between Turkey And The European Union Members With Multi Criteria Decision Making Methods]. Marmara Üniversitesi I.I.I.B. Dergisi, 35(2), 329-360.

Urkidi, L. (2010). A global environmental movement against gold mining: Pascua-Lama in Chile. Ecological Economics, 70(2), 219-227. http://dx.doi.org/10.1016/j.ecolecon

Urkidi, L., \& Walter, M. (2011). Dimensions of environmental justice in anti-gold mining movements in Latin America. Geoforum, 42(6), 683-695. http://dx.doi.org/10.1016/j.geoforum

Visser, W. 2008. Corporate social responsibility in developing countries. In A. Crane, A. McWilliams, D. Matten, J. Moon, \& D. S. Siegel (Eds.), The Oxford handbook of corporate social responsibility (pp. 473-499). Oxford: Oxford University Press. http://dx.doi.org/10.1093/oxfordhb/9780199211593.001.0001

Vural, A., Çavuşoğlu, İ. \& Demir-Şahin, D. (2013). Gümüşhane ili madencilik ve yeraltı kaynakları. In İ. Günaydın (Ed), Gümüşhane İli SWOT analizi 2013 (pp. 35-55). Gümüşhane: Gümüşhane University Press.

Warhurst, A. (2001). Corporate citizenship and corporate social investment: Drivers of tri-sector partnerships. Journal of Corporate Citizenship, 2001(1), 57-73. http://dx.doi.org/10.9774/GLEAF.4700.2001.sp.00008

Wheeler, D., Fabig, H., \& Boele, R. (2002). Paradoxes and dilemmas for stakeholder responsive firms in the extractive sector: Lessons from the case of Shell and the Ogoni. Journal of Business Ethics, 39(3), 297-318. http://dx.doi.org/10.1023/A:1016542207069

Yakovleva, N., \& Vazquez-Brust, D. (2012). Stakeholder perspectives on CSR of mining MNCs in Argentina. Journal of Business Ethics, 106(2), 191-211. http://dx.doi.org/10.1007/s10551-011-09894

Zaim, S., Sevkli, M., Akdağ, H. C., Demirel, O. F., Yayla, A. Y., \& Delen D. (2014). Use of ANP Weighted Crisp and Fuzzy QFD for Product Development. Expert Systems with Application, 41(9), 4464-4474. http://dx.doi.org/10.1016/j.eswa.2014.01.008

\section{Notes}

Note 1. A similar classification has been made for Argentina by Mutti et al. (2012) and Yakovleva and Vazquez-Brust, (2012).

Note 2. For further discussion, see Carroll, (1999).

Note 3. For further discussion, see Ozen, (2009a) and Ozen (2009b).

Note 4. The group consist of researchers of the current study and two academicians specialised on CSR.

\section{Copyrights}

Copyright for this article is retained by the author(s), with first publication rights granted to the journal.

This is an open-access article distributed under the terms and conditions of the Creative Commons Attribution license (http://creativecommons.org/licenses/by/3.0/). 